UDC $621.396 .4(045)$

DOI: $10.18372 / 1990-5548.56 .12945$

${ }^{1}$ O. I. Lysenko,
${ }^{2}$ O. M. Tachinina,
${ }^{3}$ I. V. Alekseeva

\title{
ALGORITHM OF OPTIMAL CONTROL OF UAV GROUP
}

${ }^{1}$ Department of Telecommunications, "Igor Sikorsky Kyiv Polytechnic Institute", Kyiv, Ukraine ${ }^{2}$ Department of Automation and Energy Management, National Aviation University, Kyiv, Ukraine

${ }^{3}$ Department of Mathematical Analysis and Probability Theory, "Igor Sikorsky Kyiv Polytechnic Institute", Kyiv, Ukraine

E-mails: ${ }^{1}$ lysenko.a.i.1952@gmail.com, ${ }^{2}$ tachinina5@gmail.com, ${ }^{3}$ alexir1@ukr.net

\begin{abstract}
The article proposes the algorithm of optimal control of unmanned aerial vehicle group allowing to set maneuvers of unmanned aerial vehicles, to estimate the coordinates of current position of unmanned aerial vehicle relative to specified trajectory; and to identify the optimal moments of group maneuvers. The synthesized algorithm generates the optimal control of motion of current position mark to the predetermined position taking into account the specified quality criterion, and calculates the optimum time instant and the phase coordinate of unmanned aerial vehicle group separation.
\end{abstract}

Index Terms - Compound dynamic system; optimal control; branching path.

\section{INTRODUCTION}

Currently the unmanned aerial vehicles (UAVs) are widely used to monitor crisis situations and obtain on-line data in emergency area.

The UAVs are the most reliable and safe sources of information for land groups during rescue operations. The UAVs conduct operational reconnaissance and detailed survey of the terrain, it allows defining timely situation and making decisions to coordinate actions of rescue teams.

To solve such tasks a group application of the UAVs is promising.

The advantage of using the UAVs group becomes obvious in tasks where it is possible to divide a complex task into several particular tasks performed by separate vehicles, e.g. during monitoring large areas in a short time; for providing communication with mobile subscribers for effective interaction of ground search and rescue services; for transportation and dropping small-sized loads to a specified point at the operator's command, that is difficult when using single UAVs [5], [6].

At the same time, control of UAVs group is more complicated than control of a single vehicle [7], [10].

This is due to the fact that in addition to control of flight and actions of vehicle itself, it is necessary to provide a certain relationship and consistency of its actions with other participants of the group, taking into account the group task.

For group control of UAVs, this article proposes to use a polyergatic system of motion control. The functioning diagram of polyergatic system of UAVs group motion control is shown in Fig. 1.

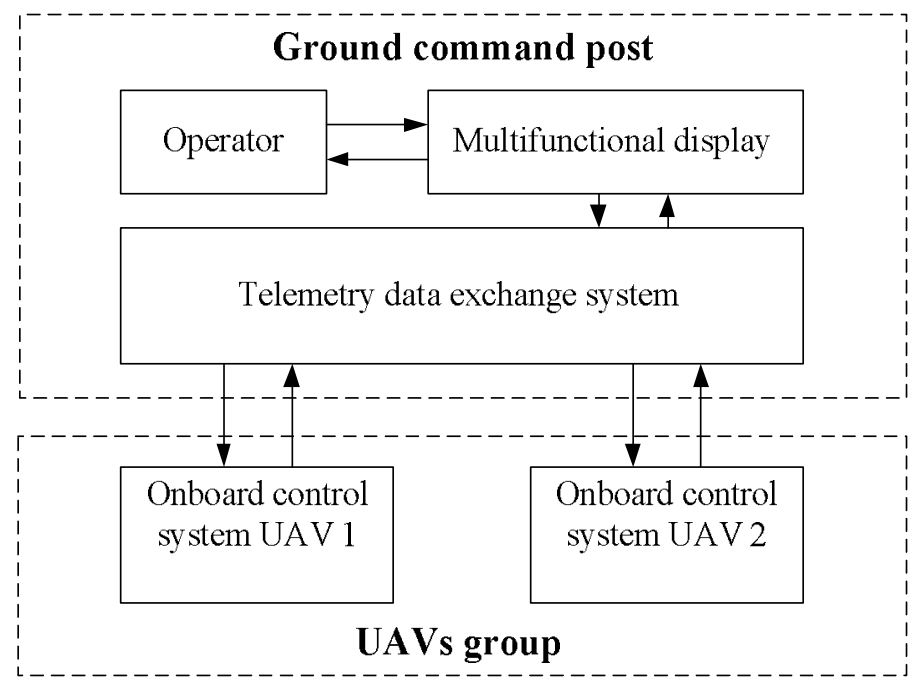

Fig. 1. The polyergatic system of UAVs group motion control 
In solving a general task planning of UAVs' paths is assigned to the operator for such method of control (Fig. 1).

The operator should solve a navigation task, i.e. assign a program path for the UAVs group, phase coordinate of group separation, time period when separation is allowed.

However, in addition to a navigational task, there is the task of retaining (stabilizing) the group and single UAVs on the program path of motion and assigning the most favorable time for separation within a specified time interval.

To solve these tasks the operator needs to have a special decision-making device that, by performing the function of "smart prompter", would help him to set UAV maneuvers, to evaluate the coordinates of their current location relative to a given path, and to identify the optimal moments for group maneuvers.

This article covers process of development of the algorithm for the "smart prompter" of ground command post's multifunctional display (MFD).

\section{PROBLEM STATEMENT}

To develop an algorithm for optimal control of the motion of the UAV group, it is proposed to use the theory of branching paths [8]. The concept of applying this theory for solving the tasks of UAVs group control is shown in Fig. 2.

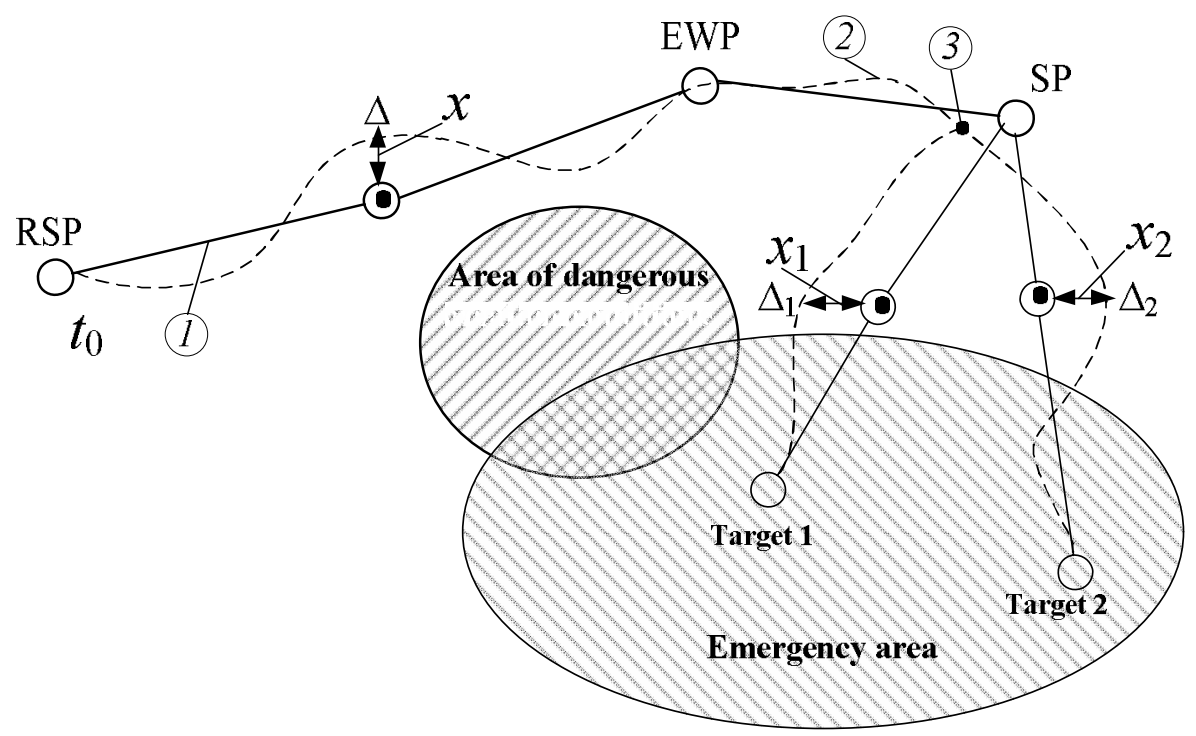

Fig. 2. Information view on the operator's MFD

During algorithm development the following designations are used: RSP is the starting point of route; EWP is the enroute waypoint; SP is the point of separation of UAVs group (Fig. 2); $\Delta$ is the mark of current position of the group $\Delta_{i}(i=1,2)$ - mark of current position of $i$ th UAV after separation; $\Theta$ is the mark of given position of the group or a separate $\mathrm{UAV} ; l$ is the path of UAV group's movement with route points, obtained as a result of navigation calculation; 2 is the actual motion path; 3 is the actual point of separation of the group; $x$ or $x_{i}(i=1,2)-$ distance between specified and current position of the group or single UAV.

In order to reproduce physically the flight pattern of UAVs group, the information (Fig. 2) can be shown on the MFD, where the operator observes air situation in emergency area, weather conditions, monitors for position of cargo dropping target.

Due to the effect of various disturbances, the current position of the UAVs group or single UAVs differs from the specified one.
The "smart prompter" algorithm produces optimal control of the current position mark to specified position according to given quality criterion and calculates the optimal time and phase coordinate of the group separation.

The command values of optimal control and time of separation are directed in the UAV's airborne control system for processing. The evolution of the current position mark on the MFD near the program path is usually described by deterministic or stochastic linear differential equations [2].

Note that the metric of space in which the task is solved is used as $x$ or $x_{i}(i=1,2)$.

The possibility of representing the UAV group with a single mark on the MFD along the path between RSP points and 3 is explained by the fact that the geometric dimensions of the UAV are less in several orders of magnitude than the distance they move, therefore this assumption is correct for the optimization of branching paths [6]. 


\section{PROBLEM SOLUTION}

It is assumed that the UAV group consists of two vehicles, the navigational task has been solved and the linear deterministic model of motion of the mark of current UAV position relative to the specified position is considered [3], [4]:

$$
\dot{x}={ }_{q} a_{q} x(t)+{ }_{q} b_{q} u(t)
$$

where ${ }_{q} x(t) \in \mathrm{E}^{1},{ }_{q} u(t) \in \mathrm{E}^{1}, q$ are indices of path sections along which the UAVs are moving, 1 is the section of joint motion of the UAVs $\operatorname{group}(q=1,11,12) ; 11,12$ are sections of motion of detached UAVs after separation. The diagram of the branching path is shown in Fig. 3.

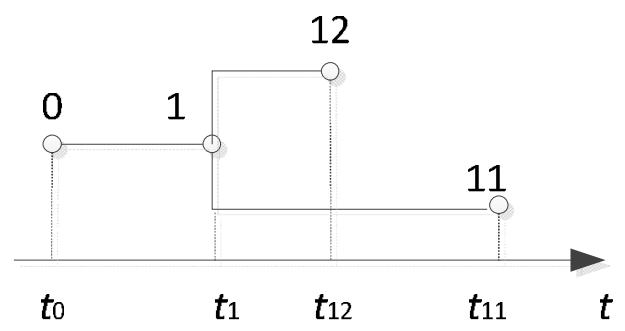

Fig. 3. The diagram of branching path.

The operator needs to specify the coordinate of start point ${ }_{1} \hat{x}\left(\hat{t}_{0}\right)$ of the UAV group's joint motion, time $\hat{t}_{1}$ and coordinate of the UAV group separation point ${ }_{1} \hat{x}\left(\hat{t}_{1}\right)$, in order the UAV " 11 " reaches the point with coordinate ${ }_{11} x\left(t_{11}\right)=4$ in $t_{11}=6 \mathrm{~s}$ after start of the joint movement and subsequent separation and the UAV " 12 " reaches point ${ }_{12} x\left(t_{12}\right)=6.92$ after $t_{12}=4 \quad \mathrm{~s}$, where the coordinates are measured in conventional distance units, minimizing the criterion

$$
\begin{aligned}
J=\frac{1}{2}\left\{{ }_{1} F_{1} x^{2}\left(t_{1}\right)+\int_{t_{0}}^{t_{1}}\left[\begin{array}{l}
{ }_{1} Q_{1} x^{2}(t)+ \\
{ }_{1} R_{1} u^{2}(t)
\end{array}\right] d t\right. \\
\left.+\sum_{\mathrm{j}=1}^{2} F_{1 j} F_{1 j} x^{2}\left(t_{i j}\right)+\int_{t_{0}}^{t_{1 j}}\left[\begin{array}{l}
\left.{ }_{1 j} Q_{1 j} x^{2}(t)+\right] \\
{ }_{1 j} R_{1 j} u^{2}(t)
\end{array}\right] d t\right\},
\end{aligned}
$$

where ${ }_{1} F=0.3 ;{ }_{11} F=0.1 ;{ }_{12} F=0.2 ;{ }_{1} Q=2 ;{ }_{11} Q=1$; ${ }_{12} Q=1 ;{ }_{1} R=2 ;{ }_{11} R=1 ;{ }_{12} R=1$.

To solve task (1), (2), where it is assumed that ${ }_{1} a=-2.5 ;{ }_{11} a=-1 ;{ }_{12} a=-1.5 ;{ }_{1} b=1 ;{ }_{11} b=0.5$; ${ }_{12} b=0.5$, we use Bellman's principle of optimality [1].

On the assumption of (1) - (2), the expression for optimal control value will have the form

$$
\begin{aligned}
& { }_{q} \hat{u}(t)=-{ }_{q} R^{-1} b_{q}^{\mathrm{T}}{ }_{q} P(t)_{q} \hat{x}(t) \\
& t \in\left[t_{q^{*}}, t_{q}\right]\left(q=1, q^{*}=0 ; q=11,12, q^{*}=1\right),
\end{aligned}
$$

where ${ }_{q} P(t)$ is the solution of the differential equation

$$
\begin{array}{rl}
{ }_{q} P(t)=-{ }_{q} & P(t)_{q} a-{ }_{q} a^{T}{ }_{q} P(t) \\
& +{ }_{q} P(t)_{q} b_{q} R^{-1}{ }_{q} b^{T} P(t)-{ }_{q} Q,
\end{array}
$$

for the corresponding boundary conditions

$$
\begin{aligned}
{ }_{q} P\left(t_{q}\right)= & { }_{q} F(q=11,12),{ }_{1} P\left(t_{1}\right) \\
& ={ }_{1} F+{ }_{11} P\left(t_{1}\right)+{ }_{12} P\left(t_{1}\right)(q=1) .
\end{aligned}
$$

The main difference between the proposed algorithm for the optimal control calculating (3) - (5) from the known one is in the boundary condition (5) for $q=1$ when the boundary value for auxiliary variable ${ }_{1} P\left(t_{1}\right)$ is calculated taking into account the values of the auxiliary variables ${ }_{11} P(t)$ and ${ }_{12} P(t)$ at the left end of branches " $1-11$ " and " $1-12$ " at $t=t_{1}$.

Using expressions (3) - (5) for the scalar problem (1) - (2), we obtain the following analytical expressions for calculating the phase coordinates and auxiliary variables included in the expression for optimal control calculating:

$$
\begin{aligned}
& { }_{q} \hat{x}(t)={ }_{q} x\left(t_{q}\right) \operatorname{ch}\left[\sqrt{\delta_{q}}\left(t_{q}-t\right)+\varphi_{q}\right] \operatorname{ch}^{-1} \varphi_{q}, \\
& { }_{q} P(t)={ }_{q} R\left\{{ }_{q} a+\sqrt{\delta_{q}} \operatorname{th}\left[\sqrt{\delta_{q}}\left(t_{q}-t\right)+\varphi_{q}\right]\right\}_{q} b^{-2}, \\
& t \in\left[t_{q^{*}}, t_{q}\right]\left(q=1, q^{*}=0 ; q=11,12, q^{*}=1\right),
\end{aligned}
$$

where $\varphi_{1 j}=\operatorname{arth}\left[\left(-{ }_{1 j} a+{ }_{1 j} b_{1 j}^{2} F_{1 j} R^{-1}\right) \delta_{1 j}^{-\frac{1}{2}}\right]$,

$$
\begin{gathered}
\delta_{1 j}={ }_{1 j} Q_{1 j} b^{2}{ }_{1 j} R^{-1}+_{1 j} a^{2}(j=1,2), \\
\varphi_{1}=\operatorname{arth}\left\{\left[-{ }_{1} a+{ }_{1} b^{2}\left({ }_{11} P\left(\hat{t}_{1}\right)+{ }_{12} P\left(\hat{t}_{1}\right)+{ }_{1} F\right)\right] \delta_{1}^{-\frac{1}{2}}\right\}, \\
\delta_{1}={ }_{1} Q_{1} b^{2}{ }_{1} R^{-1}+{ }_{1} a^{2} .
\end{gathered}
$$

The time $\hat{t}_{1}$ of separation of the UAV group is found from the condition ${ }_{11} \hat{x}\left(\hat{t}_{1}\right)={ }_{12} \hat{x}\left(\hat{t}_{1}\right)$. Then, substituting $\hat{t}_{1}$ in the expressions for $\hat{t}_{1}$, we calculate the coordinates of separation point and further, assuming in expression (6) that $t=t_{0}=0$ at $q=1$, we find ${ }_{1} x\left(\hat{t}_{0}\right)$. 
As a result of the calculations, we get ${ }_{1} x\left(\hat{t}_{0}\right)=1.17, \hat{t}_{1}=1,094 \mathrm{~s},{ }_{1} x\left(\hat{t}_{1}\right)=1.59$. Figure 4 shows the graphs of joint and separate movement of the UAV.

The scientific novelty of the proposed algorithm lies in the fact that a branching path is considered as a model of UAVs group motion in the ergatic control system for the first time. Holding (stabilization) on this branching path is carried out by a criterion minimizing total energy expenditures and allowing to improve quality of transient processes.

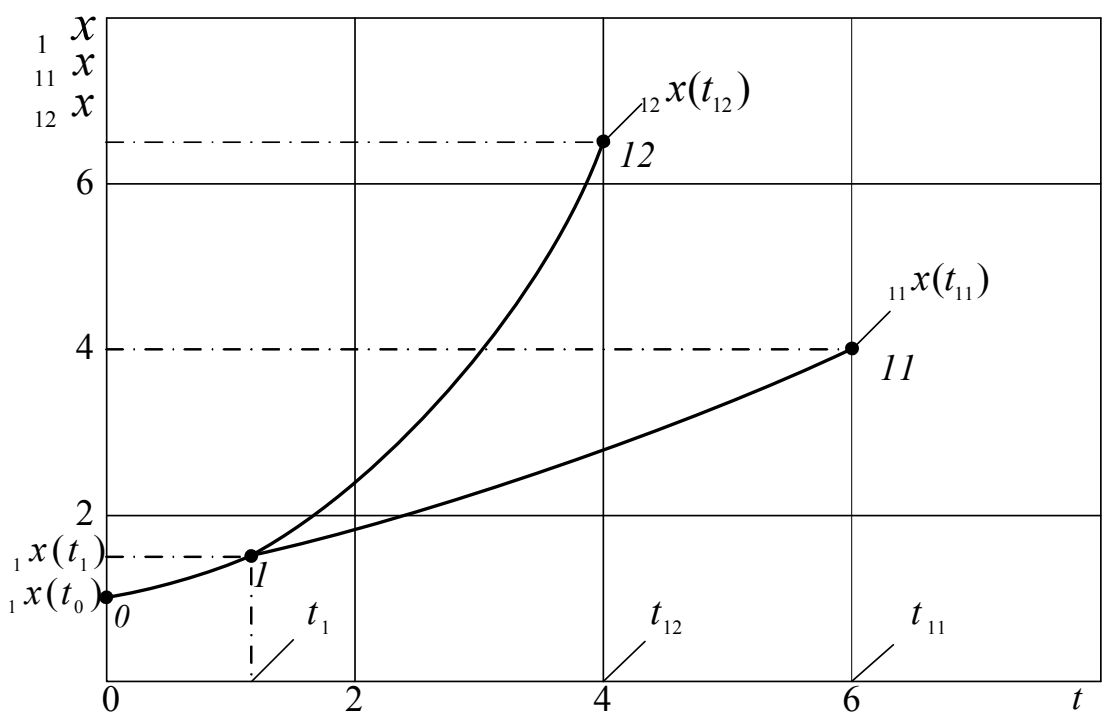

Fig. 4. Graphs of joint and separate movement of the UAV

Until now the task of holding a group of UAVs on a branching path was solved without considering the branching effect. The article for the first time proposes the algorithm how to take into account the branching effect in the task of UAVs group stabilization (holding)/

In this case, the time instants and coordinates for breaking-up of UAVs group are optimally selected.

\section{CONCLUSIONS}

The article proposes the algorithm of "smart prompter", which allows setting the UAV's maneuvers; evaluation the coordinates of the UAV's current position relative to the specified path; and identification the optimal moments for group maneuvers.

The synthesized algorithm produces the optimal, as regards of a specified quality criterion, control of the movement of the current position mark to a specified position and calculates the optimal time and phase coordinate of the UAV group separation.

The conducted research showed that the obtained algorithm does not apply fundamental limitations on the possibility of its realization.

\section{REFERENCES}

[1] A. E. Bryson and Y.-C. Ho, Applied Optimal Control. New York-London-Sydney-Toronto. John Wiley \& Sons, 1975, $481 \mathrm{p}$.
[2] M. A. Richards, Fundamentals of Radar Signal Processing. McGraw-Hill Education, 2014, 472 p.

[3] T. Ashchepkov, Optimal control of discontinuous systems. Novosibirsk, Nauka, 1987, 226 p. (in Russian).

[4] A. P. Sage and Ch. C. White, Optimum Systems Control. Moscow, Radio and connection, 1982, 392 p. (in Russian).

[5] O. Lysenko, O. Tachinina, I Alekseeva, and S. Chumachenko. "The Scenario-Based Approach for Control of Multi-Object Dynamic System Motion," 3rd International Conference: Actual problems of unmanned aerial vehicles developments, October 1315, 2015. Organized by IEEE Ukraine Section Joint SP/AES Chapter and the National Aviation University (Kyiv), pp. 305-308. (in Ukranian).

[6] O. Lysenko, I. Uryadnikova, S. Valuiskyi, S. Chumachenko, and etc. "Increasing of manet throughput using quasi-optimal UAVs placement control," Liptovsky Mikulas, Slovak Republic: Armed Forces Academy. Science\&Military. no.1, vol. 8, 2013, pp. 24-35. (in Slovak Republic).

[7] O. Lysenko, O. Tachinina, I. Uriadnikova, I. Alekseeva, and S. Chumachenko, "Features of unmanned aerial vehicles group dynamics and control," International Conference "The safety management system 2016," February 22-27, 2016. Liptovsky Mikulas, Slovak Republic, Armed Forces Academy of General Milan Rastislav Stefanik, Liptovsky Mikulas, Slovakia. pp. 391-397. (in Slovak Republic). 
[8] O. Lysenko, O. Tachinina, and S. Chumachenko, "The problem statement of branching paths theory for solution of search and rescue task in the area of emergency situation". Technical mechanics, Dnepropetrovsk, vol. 1, pp. 73-78, 2015. (in Ukranian).
[9] O. Sushchenko "Design of two-axis robust system for stabilization of information-measuring devices operated at UAVs" in Proc. IEEE 3rd Int. Conf. Actual Problems of Unmanned Aerial Vehicles Developments, October 13- 15, 2015, pp. 198-201. (in Ukranian)

Received March 01, 2018

Lysenko Alexander. Doctor of Engineering Science. Professor.

Department of Telecommunications, "Igor Sikorsky Kyiv Polytechnic Institute", Kyiv, Ukraine.

Education: Kiev Higher Military Aviation Engineering School, Kyiv, Ukraine, (1974).

Research interests: the dynamics of flight control systems.

Publications: more than 300 papers.

E-mail: lysenko.a.i.1952@gmail.com

Tachinina Helen. Candidate of Science (Engineering). Associate Professor.

Department of Automation and Energy Management, National Aviation University, Kyiv, Ukraine.

Education: Kyiv International University of Civil Aviation, Kyiv, Ukraine, (1999).

Research area: The methods of optimal control of compound dynamic systems.

Publications: 86 .

E-mail: tachinina5@gmail.com

Alexeeva Irina. Candidate of Science (Physics and Mathematics). Associate Professor.

Department of Mathematical Analysis and Probability Theory, "Igor Sikorsky Kyiv Polytechnic Institute", Kyiv, Ukraine.

Education: Kyiv State University Shevchenko, (1986).

Research area: mathematical modeling in scientific research.

Publications: 80 .

E-mail: alexir1@ukr.net

О. І. Лисенко, О. М. Тачиніна, І. В. Алєксєєва. Алгоритм оптимального керування групою безпілотних літальних апаратів

У статті запропоновано алгоритм оптимального керування групою безпілотних літальних апаратів, що дозволяє задавати маневри безпілотних літальних апаратів, оцінювати координати поточного положення безпілотного літального апарата щодо заданої траєкторії, ідентифікувати оптимальні моменти часу виконання групових маневрів. Синтезований алгоритм виробляє оптимальне, з урахуванням заданого критерію якості, керування рухом мітки поточного положення до заданому положенню і розраховує оптимальний момент часу $\mathrm{i}$ фазову координату поділу групи безпілотних літальних апаратів.

Ключові слова: оптимізація; динамічна система; розгалужені траєкторії; оптимальна траєкторія.

Лисенко Олександр Іванович. Доктор технічних наук. Професор.

Кафедра телекомунікацій, «Київський політехнічний інститут ім. І.Сікорського», Київ, Україна.

Освіта: Київське вище військове авіаційне інженерне училище, Київ, Україна, (1974).

Напрямки наукової діяльності: динаміка польоту, системи керування.

Кількість публікацій: більше 300 наукових робіт.

E-mail: lysenko.a.i.1952@gmail.com

Тачиніна Олена Миколаївна. Кандидат технічних наук. Доцент.

Кафедра автоматизації та енергоменеджменту, Національний авіаційний університет, Київ, Україна.

Освіта: Київський міжнародний університет цивільної авіації, Київ, Україна, (1999).

Напрямки наукової діяльності: методи оптимального керування складеними динамічними системами.

Кількість публікацій: 86.

E-mail: tachinina5@gmail.com

Алєкссєва Ірина Віталіївна. Кандидат фізико-математичних наук. Доцент.

Кафедра математичного аналізу та теорії ймовірностей, «Київський політехнічний інститут ім. І.Сікорського», Київ, Україна.

Освіта: Київський державний університет ім. Т. Г. Шевченка.

Напрямки наукової діяльності: математичне моделювання в наукових дослідженнях.

Кількість публікацій: 80.

E-mail: alexir1@ukr.net. 
А. И. Лысенко, Е. Н. Тачинина, И. В. Алексеева. Алгоритм оптимального управления группой беспилотных летательных аппаратов

В статье предложен алгоритм управления группой беспилотных летательных аппаратов, позволяющий задавать маневры беспилотных летательных аппаратов, оценивать координаты текущего положения беспилотного летательного аппарата относительно заданной траектории, идентифицировать оптимальные моменты времени выполнения групповых маневров. Синтезированный алгоритм вырабатывает оптимальное, с учетом заданного критерия качества, управление движением метки текущего положения к заданному положению и рассчитывает оптимальный момент времени и фазовую координату разделения группы беспилотных летательных аппаратов.

Ключевые слова: оптимизация; динамическая система; ветвящиеся траектории; оптимальная траектория.

Лысенко Александр Иванович. Доктор технических наук. Профессор.

Кафедра телекоммуникаций, Национальный технический университет Украины «Киевский политехнический институт им. И.Сикорского», Киев, Украина.

Образование: Киевское высшее военное авиационно-инженерное училище, Киев, Украина, (1974).

Направления научной деятельности: динамика полета, системы управления.

Количество публикаций: больше 300 научных работ.

E-mail: lysenko.a.i.1952@gmail.com

Тачинина Елена Николаевна. Кандидат технических наук. Доцент.

Кафедра автоматизации и энергоменеджмента, Национальный авиационный университет, Киев, Украина.

Образование: Киевский международный университет гражданской авиации, Киев, Украина, (1999).

Направления научной деятельности: методы оптимального управления составными динамическими системами.

Количество публикаций: 86.

E-mail: tachinina5@gmail.com

Алексеева Ирина Витальевна. Кандидат физико-математических наук. Доцент.

Кафедра математического анализа и теории вероятностей, «Киевский политехнический институт им. И. Сикорского», Киев, Украина.

Образование: Киевский государственный университет им. Т. Шевченко

Направления научной деятельности: математическое моделирование в научных исследованиях.

Количество публикаций: 85 .

E-mail: alexir1@ukr.net. 